\title{
Framing statelessness and 'belonging' Rohingya refugees in Bangladesh's The Daily Star newspaper
}

\begin{abstract}
Stripped of Myanmarese citizenship in 1982 and persecuted for three decades, stateless Rohingya have long found precarious refuge in neighbouring Bangladesh. This study explores the framing of the Rohingya in Bangladesh's largest circulating English language newspaper The Daily Star, to examine how one of the nation's most prominent newspapers of record framed refugee migration into the country. Analysing two distinct random samples of news stories published on The Daily Star website between 1 December 2011-31 November 2012 and 1 August 2017-31 October 2017, this article argues that The Daily Star's press identity, defined though a nationalist frame, failed to successfully deliver human rights-based journalism though a globalist Fourth Estate imperative.
\end{abstract}

Keywords: Bangladesh, conflict media, Fourth Estate, human rights journalism, Myanmar, refugees, Rohingya

\section{KASUN UBAYASIRI}

Griffith University, Brisbane

\section{Introduction}

-HE ROHINGYA have long been persecuted in Myanmar. Stripped of citizenship in 1982 and discarded as recent interlopers from Chittagong during British colonial occupation, successive Burmese governments have dismissed their historical links to the region and relegated the Rohingya to a purgatory of statelessness.

Their precarious existence in Myanmar's south-western state of Rakhine became even more tenuous after decades of simmering ethnic tension with government-backed Rakhini Buddhists escalated into communal violence in June 2012. In the past five years alone the Rohingya have faced two distinct waves of violence - the June 2012 clashes and the October 2012 resurgence of violence, sparked by false claims that a Rohingya man had raped and murdered a 27-year-old Rakhini Buddhist woman (International Crisis Group, 2016); and the spread of violence following the Arakan Rohingya Salvation Army's alleged 
attack on Myanmarese government forces on 9 October 2016 and 25 August 2017.

A large number of Rohingya refugees have migrated into Bangladesh as a direct result of these three decades of persecution. While the actual numbers remain uncertain, in October 2012 the UNHCR reported there were 28,000 Rohingya living in the Nayapara and Kutupalong refugee settlements in Cox's Bazaar, with more than 200,000 others living outside in a 'refugee-like situation' (UNHCR, 2012). Most of these outside refugees had migrated prior to the 2012 violence but had not benefited 'from legal status or documentation' since the Bangladeshi government suspended refugee registration in mid-1992, resulting in 'protection gaps and increased vulnerability'. In April 2013, Human Rights Watch wrote ' ...violence since June (2012 had) displaced at least 125,000 Rohingya and other Muslims, and a smaller number of Arakanese, to internally displaced person (IDP) camps,' (HRW, 2012, p 6) in Myanmar. Bangladesh's decision to close its border at that time meant few Rohingya were able to seek formal refuge inside Bangladesh.

In August 2018, the UNHCR claimed 723,000 Rohingya had fled to Bangladesh since August 25, 2017 adding to the 307,500 Rohingya refugees already living in Bangladesh (UNHCR, 2018). The European Civil Protection and Humanitarian Aid Operations October 2017 factsheet noted 'over 530,000 Rohingyas have fled across the border into Bangladesh', following the August 2017 violence, adding to 87,000 who had already fled in the initial resumption of violence in October 2016 (European Commission, 2017).

The persecution of the Rohingya in Myanmar and their precarious refuge in Bangladesh is a product of socio-political othering that has reduced the Rohingya to one of the largest stateless communities in the world, not belonging to either Myanmar or Bangladesh. Their statelessness is best understood through a flawed historicity that views the border between the modern nation states of Bangladesh and Burma as historically enduring.

Based on an understanding of generations of human movement across porous and shifting borders, and the historical ebb-and-flow of religio-cultural identity among heterogeneous peoples of the region, this article posits that seeking refuge in Bangladesh is not only a fundamental human right, but one that is backed by a centuries-long historical precedence. This article also argues that the othering of Rohingya refugees frequently observed in Bangladesh's largest circulating English language newspaper The Daily Star, cannot be historically validated or defended through the normative rationale of a global Fourth Estate press.

This study looks at coverage of the Rohingya in a very specific space within the Bangaladeshi press, namely the county's largest circulating English language newspaper, The Daily Star. Considering news media can simultaneously mould public opinion and be a reflection of public opinion, the narrow focus on just one publication is selected to explore how the English-educated elite may be both 
influenced by its coverage and how they might otherwise view Rohingya refugees. In doing so, two other significant segments of the Banagaldeshi news media are deliberately omitted in this study - the vernacular press, and a small number of Cox's Bazaar and Rohingya-focused alternative media, such as coxsbazarvision and Rohingya Vision. While such omission reduces the generalisability of findings to the entirety of the Bangadeshi press, it presents an opportunity for an in-depth discussion of the narrowly defined media space at the core of this investigation.

This study also acknowledges the growing Buddhist-Muslim fault line, with the spread of chauvinistic religio-nationalism in the three Theravada Buddhist counties in the region: Sri Lanka, Thailand and Myanmar; and its coverage in respective local media. While acknowledging the need to further explore the mediatisation of this fault-line, both within the respective national spheres and within the transnational space where news media and ideas are shared, such deliberations are also deemed to be beyond the scope of this study, which is positioned outside of the Myanmarese news media space, and as such, the political sphere of its Buddhist-Muslim fault line.

\section{Arakan: The people of the frontier state.}

The othering of the Rohingya must be understood through the misrepresentation of the nation state as historically enduring sovereign land linked to an unchanging religio-cultural identity, when in fact identities change, boundaries shift and people move. The people and their identity in the Rakhine are no different. It was this understanding of identity as transitional that led to Krishna's assertion for the "need to conceive South Asia as a space marked by highly decentralised nation-states with substantial degrees of provincial or regional autonomy and a pluralist sense of national identity' (1999, p. xviii).

Separated from central Myanmar by the Arakan mountains, Rakhine, or Arakan as it was formerly known, has long remained the frontier between Islam, Hinduism and Buddhism. Kyaw Minn Htin (2011) claims Buddhism had reached early Arakanese kingdoms, especially Dhaññavatī and Vesālī, as early as the fifth century, well before Theravada Buddhism was officially installed as the state religion of the Burmese court during the reign of King Anawrahta (pp. 1044-1077) of the Pagan Dynasty (Schober, 2006, pp. 75-76).

Eaton (1993) notes Islam reached Arakan though Turkic general Muhammad Bakhtiyar's invasion of north-western Bengal in 1204, but Islamic jurisprudence written by Iranian jurists following the invasion had negotiated between state authority and theological power resulting in a quasi-separation of power-where political and administrative authority was decentralised among numerous regional chiefs, while the symbolic primacy of the caliph in Baghdad was preserved through perceived religious power which was wielded, in reality, by living Sufi 'saints'. Such decentralisation of authority enabled a complex power dynamic 
to form between Indo-Turkish rulers, Sufi saints and Bengali Hindu elite (Eaton, 1993, pp. 22-70) over the next two centuries.

Simultaneous to shifting religio-cultural identity, Pearn (1944) notes 'politically and historically Arakan was at various times an independent kingdom of some extent and power prior to its conquest in 1784-85 by Bodawpaya, son of Alaungpaya, who founded the last dynasty of kings in Burma proper'. At the height of their power, Arakanese kings occupied parts of Bengal, including Chittagong from 1459 to1666 (Farzana, 2011; Bhattacharya, 1927). Thus, geographically separated from Burma 'proper' by the Arakan mountains, the region developed somewhat separately from Burma - a buffer between 'East Bengal' and Burma proper (Krishna, 1999; Liang, 1990).

Such an understanding of history casts doubt over the historical accuracy of purported Burmese dominion over Arakan, especially considering the Burmese empire's own hold on Arakan was short lived, with the region falling to British rule following the first Anglo-Burmese war (Grundy-Warr \& Wong, 1997). The British eventually annexed all of Burma in 1886, when it became the Burma province of the British Indian Raj. However, in the modernist drawing of boundaries at the time of Indian and Burmese independence from the British, Arakan was handed over to Burma - its last invader.

Morshed (2001) notes 'present-day Bangladesh and Burma have interacted over the centuries and there were well-established trade routes and free movement of peoples before the British era'. This historic process of human movement across the border was further relaxed following the British annexation of Burma, allowing uninterrupted migration from the Indian subcontinent into Burma from 1886 onwards, until Indian independence and partition in 1947, and Burmese independence the following year. Such migration has resulted in both a linguacultural syncretism and the scattering of heterogeneous populations across the Bangladesh-Myanmar border.

What is also clear from this diverse and contested history of the region, and perhaps more germane to the core argument of this paper, is that Chittagong and Cox's Bazar in present day Bangladesh have long been a safe haven for Arakanese refugees during times of Burmese invasions, and more controversially a place to mobilise counter-offensives against invading Burmese armies. The Cox's Bazar District itself was named after Hiram Cox, a British officer who organised refuge for more than 200,000 mostly Muslim Arakanese who fled the region following the 1784 Burmese invasion (Haksar, 2009, pp110-111).

While Arakanese kingdoms should not be conflated with the claim of a Rohingya kingdom, nor the manifestations of Arakanese identity with Rohingya nationalist identity, or for that matter historical Arakanese refugees with that of present day Rohingya, it must certainly add credence to the legitimacy of the Rohingya to seek refugee status inside Bangladesh. This understanding 
of historical 'reality' should then be reflected in the contemporary news media coverage of the Rohingya.

\section{The theoretical underpinning: Agenda-setting and framing}

The importance of the news media in interpreting reality is based on the notion of cognitive media effects - the argument that media coverage both influences and is influenced by public opinion. In the case of this research, such an understanding of cognitive media effects underscores how the mediated reality of legitimacy and belonging of Rohingya refugees is constructed by the Bangladeshi press and by extension the Bangladeshi community. The news media in this sense is seen both as a reflection of Bangladeshi social attitudes and a factor influencing future changes in attitude.

Gamson and Modigliani present media coverage and its impact on public opinion and attitude as a system in dynamic equilibrium where one informs and influences the other. They state "we do not... argue that changes in media discourse cause changes in public opinion. Each system interacts with the other: media discourse is part of the process by which individuals construct meaning, and public opinion is part of the process by which journalists and other cultural entrepreneurs develop and crystallise meaning in public discourse' $(1989$, p. 2).

Theoretical work on agenda setting posits media consumers are more likely to recall news events that receive significant coverage - suggesting the media is able to influence what people think about by selecting some media agendas and not others (Baumgartner \& Jones, 2010; McCombs, 1997; Zaller, 1992). McCombs and Shaw (1972) claim news media assigns importance through the processes of news selection, the relative positioning of news and the frequency of coverage provided. Seminal studies on media framing, suggest the news media not only tells "readers what to think about" as posited in agenda setting theory, but they do indeed frame news in such a way so as to influence how readers or their audience think.

Entman (1993) notes that frames are different from agendas, suggesting salience in frames is not achieved through mere repetition. He presents the concept of framing as an active process, arguing that framing essentially involves selection and salience. Entman notes 'to frame is to select some aspects of a perceived reality and make them more salient in a communicating text, in such a way as to' define problems, diagnose causes that create the problem, make moral judgements by evaluating the causal agents, and offer remedies to the problem (Entman, 1993, p. 52). Gitlin notes media frames are 'largely unspoken and unacknowledged, organise [sic] the world both for journalists who report it and, in some important degree, for us who rely on their reports' (1980, p7). According to frame theory, news frames therefore play a crucial role in both the construction of media frames by news makers, and the subsequent unpacking and 
interpreting of news frames by audiences through the application of individual frames (De Vreese, 2005; D’Angelo \& Kuypers, 2010).

Within that context, this paper focuses on how The Daily Star, Bangladesh's largest circulating English language newspaper, framed Rohingya refugees. Considering frames are observable along the entire communication process (de Vreese, 2005; D’Angelo \& Kuypers, 2010; Gamson \& Modigliani, 1987; Scheufele 1999); and that they are socially constructed, (McQuail, 2010) this study attempts to isolate media frames found within the newspaper text to glean prevailing social perceptions of the Rohingya among both the journalists or opinion-writers who construct the news frames and the English-speaking Bangladeshi elite influenced by them.

The study analysed a random sample of 100 news stories published on The Daily Star website between 1 December 2011-31 November 2012; and a further 50 reports published between 1 August 2017-31 October 2017. The articles were selected through a site-specific Google search of The Daily Star website, and subjected to a detailed qualitative frame analysis to establish manifest and latent frames in the text. The analysis is qualitative and inductive, in that the study is aimed at identifying frames and not merely quantifying its prevalence. As de Ruyter and Scholl (1998) note 'qualitative research does not measure, it provides insight', thus arguing the importance of a qualitative frame analysis in producing insight, whereas a quantitative analysis focused on counting repetition would provide little insight in to the nuanced use of frames and their positioning within broader social-discourse.

While the observations of a single publication are not universal, it is argued The Daily Star as the largest circulating English daily newspaper is central in illuminating the politico-ideological perspectives of Bangladeshi elite. Within the same vein, the detailed inductive study of frames in a singular publication also provides a crucial benchmark for future longitudinal studies on multiple English and vernacular press reports.

\section{Framing the Rohingya: Identity, legitimacy and belonging}

On 5 December 2012, Bangladeshi Prime Minister Sheikh Hasina arrived in Myanmar on a three-day official visit - the first Bangladeshi Prime Minister to visit neighbouring Myanmar in eight years. The visit was an attempt to foster a relationship with the new Burmese government, and its reformist President Thein Sein, after decades of military rule and isolation. Notable on the agenda was the thorny issue of repatriating Burmese Rohingya refugees from Bangladesh. '...[R]epatriation of Rohingya refugees, energy cooperation, maritime dispute, trade and connectivity is high on the agenda,' The Daily Star reported.

During this optimistic era of renewed bilateral ties, The Daily Star's 'othering' of the Rohingya emerged though three fundamental frame sets: 


\section{// the Rohingya as an impediment to Bangladeshi prosperity}

\section{// Rohingya as victims}

\section{// intruders of Bangladeshi sovereignty}

\section{The Rohingya as an impediment to Bangladeshi prosperity}

The Rohingya discourse in The Daily Star during the time period analysed, was framed within Bangladesh's renewed relations with the new Myanmar government, and the otherness of the Rohingya is manifest this coverage. The inductive analysis of the 'impediment to prosperity' frameset suggests the existence of three subsets;

\section{// the Rohingya as an impediment to Bangladeshi prosperity}

/// impediment to economic growth and undeserving of benefiting from it

Because:

\section{///Rohingya as economic migrants}

///charity as limited by availability of economic surplus

Impediment to economic growth and undeserving of benefiting from it: The framing of the Rohingya as an impediment to economic growth and undeserving of benefiting from such growth appears as two interrelated frames in the newspaper narrative.

'Bangladesh's future development hinges on some critical projects in Chittagong and the hill tracts areas, such as the Chittagong port, special economic zones and deep-sea ports, which are very close to Myanmar,' the newspaper wrote on 21 September 2017, citing a report produced by a Dhaka-based think-tank. It quoted the report as saying, 'A possible conflict with Myanmar can hamper Bangladesh's efforts for integration with Southeast Asian countries.' (The Daily Star, September 21, 2017). The narrative, while embracing regional co-operation, views the Rohingya as a barrier preventing Bangladeshi citizens from reaping economic benefits, which then justifies excluding Rohingya refugees from the benefits of growth.

Bangladesh-Myanmar relations are framed in a positive and optimistic light of regional co-operation, portraying a transition from military rule to civilian democracy, and with it and end to a 20 -year isolationist policy. The transition is presented as positive in that it opens up the possibility of greater co-operation between Bangladesh and Myanmar, paving the way for 'energy cooperation... trade and connectivity' (The Daily Star, December 5, 2011, p. 1); and geographical connectivity though "direct road and air links between the two countries" (The Daily Star, December 3, 2011).

The Rohingya are framed as a 'problem' with a single solution - repatriation to Myanmar. The coverage however, is not explicit on how the Rohingya 
act as an impediment to Bangladeshi prosperity, but it is implicit in presenting the Rohingya as undeserving of any potential bounty. Within the context of Entman's view of frames offering moral justification, this alienation is justified though another complementary frame that views them as economic migrants.

Rohingya as economic migrants: 'The Rakhine state of Myanmar, which borders Cox's Bazar, is a poverty-prone area of Myanmar. This fact forces the Rohingyas to migrate to Bangladesh for economic reasons. This continuous intrusion of Rohingyas has an alarming impact on socio-economic equilibrium of Cox's Bazar, but this fact is overlooked due to the longstanding issue of oppression on Rohingyas,' The Daily Star reported, paradoxically arguing that the Rohingya are both 'genuine' refugees and not (August 9, 2012).

The framing of the Rohingya as economic migrants draws from a higher order meta-frame that views 'economic migration' though a pejorative framework that pits them against more 'deserving refugees' (Samers \& Collyer, 2017, p. 13). Such narratives ignore a growing body of literature that presents a cogent argument that views migration beyond a simple dichotomy of genuine refugees and economic migrants (Barcus \& Halfacree, 2018). Newspaper frames in this regard tend to conceive economic prosperity though state demarcations and geographic confines. Such readings of the complex nature of migration suggests forced economic migration due to long term poverty, especially when viewed though political and economic marginalisation and persecution, are a valid form of refuge. However, the bifurcation between refugees and economic migrants, and the subsequent delineation of the two as legitimate and illegitimate, attaches a pejorative connotation to the 'economic migrant' label, which is then used to morally justify their mistreatment.

Charity as limited by availability of economic surplus: Framing humanitarian assistance through an economic narrative enables economic rationalisation of neglect and even persecution of refugees. It suggests refugees are entitled to basic needs only once the economic needs of the state and its citizens are fulfilled, thus positioning refugee needs not as a humanitarian need, but as an economic prerogative at the discretion of the state.

'Rohingyas settled in Teknaf and Ukhia upazilas (administrative regions), who now number over 600,000 , are costing us more than US\$4 million daily to feed and shelter, not counting the other half a million who came earlier,' the newspaper wrote on 30 October 2017. The cost is not sourced and would suggest US $\$ 2,433$ per annum, in country with an annual per person GDP of $\$ 1,538$. The unsubstantiated figures notwithstanding, such an argument seems justifiable given the reality of Bangladesh's own poverty. Entman asserts one of the functions of frames is to define problems (Entman, 1993, p. 52), and this frame, at least on the face of it does exactly that. However, the inherent problem with such thinking is obvious when refugees are viewed as outsiders undeserving of 
the economic benefits that are the sole entitlement of citizens. Such thinking is especially problematic considering the Rohingya are not merely foreign nationals seeking refuge in Bangladesh, they are stateless people moving from statelessness to refuge - as such they are entitled neither to Myanmar's economic wealth nor Bangladesh's.

A more logical frame in this instance would be to view wealth distribution as a regional issue - within the context of Krishna's view of Southeast Asia as a 'space marked by highly decentralised nation-states' with a 'pluralist sense of national identity' (1999).

\section{The Rohingya as victims}

The analysis of victim frames was most notably identified by Van Gorp (2005), who presented them in connection with a victim-intruder frame couplet in his research on the coverage of asylum seekers in eight Belgian newspapers. As observed in Van Gorp's study there was significant crossover between the two frame sets, more so in The Daily Star than in Van Gorp's study.

While this article draws upon Van Gorp's seminal work on the victimintruder frame, it does not attempt to quantify the frame sets in The Daily Star coverage. Instead it focuses on presenting an inductive analysis of a sub-set of frames under the victim frame, to further understand how this family of frames define problems and diagnose causes, make moral judgments and offer remedies.

\section{// Rohingya as victims}

\section{/// alleging victimisation}

/// generalisation of victimisation to all Muslims

/// shifting victimisation solely to Myanmar

/// capacity for humanitarianism as finite

The sub-frames that define problems and diagnose causes, either alleged victimisation or shifted blame for victimisation squarely to Myanmar. They also generalised the persecution to all Muslims shifting the focus away from the Rohingya - which was a thornier issue for Bangladesh.

Alleging victimisation: In alleging victimisation, the framing allows for contestation of the Rohingya's refugee status, which in turn allows Bangladesh to dismiss persecution as an internal matter for Myanmar. 'To be eligible as a refugee, there must be "well-founded fear of persecution" by the state. The present unrest emanated from an allegedly criminal act on a Buddhist female by some Rohingyas and did not arise from persecution by the authorities. It is considered as a law and order issue for Myanmar,' barrister Harun Ur Rashid wrote on 20 June 2012 (The Daily Star, June 20, 2012). This frame has mellowed over time, especially in the aftermath of the 2016-17 violence.

This is not to say the newspaper was impervious to the humanitarian drama 
unfolding along the Bangladeshi border in 2012.

Generalisation of victimisation to all Muslims: Accounts such as those of Rohingya women Rashida Begum and Syeda Khatun were common in the coverage of refugee migration. The paper said the women 'were found shocked and crying. They said Muslims were being tortured in their localities and they definitely did not want to go back' (The Daily Star, June 12, 2012), suggesting the persecution of Muslims in general rather than explicitly identifying the victims as Rohingya. At times of intense crisis, the framing is clearly sympathetic, but The Daily Star generally fell short of its Fourth Estate mandate to scrutinise power by failing to question Bangladesh's role in the humanitarian crisis though its policy of closing the border and the official channels of refuge in 2012.

Shifting victimisation solely to Myanmar: Shifting responsibility for victimisation also framed refugees as intruders - a population forced to intrude by the actions of the Myanmarese regime. A Daily Star article on June 11, 2012 reported Bangladeshi police had arrested a number of wounded Myanmar citizens, one of whom told the newspaper's correspondent he had come to Teknaf in Bangladesh on a fishing boat, after being shot by Myanmar's border security, the Nasaka forces. The same article simultaneously gave voice to the Bangladeshi border commanders who bragged about the effectiveness of the tougher border security regime which was keeping intruders at bay.

Capacity for humanitarianism as finite: This frame exonerates Bangladesh for having done its best. In this context, there is little ambiguity over the party responsible for victimisation when presenting historic claims of persecution and subsequent refugee migration into Bangladesh. The exodus of more than 200,000 Rohingya in 1978 following the Myanmar army's operation 'Dragon King', and further migration in 1991-1992 are presented without caveats, allowing the newspaper to frame the 2012 refugee crisis within a wider historic framework in which Bangladesh had already fulfilled its humanitarian obligations. The language in this frame included phrases such as 'Bangladesh had been burdened with the Rohingya' and 'influx of Rohingya refugees' (The Daily Star, December 17, 2011) strengthening claims that Bangladesh had carried the 'burden' of humanitarian assistance.

\section{Intruders of Bangladeshi sovereignty}

After a brief dalliance with a humanitarian frame, by mid-June 2012 The Daily Star again shifted to national security and territorial integrity frames, reporting Bangladeshi border guard efforts to barricade against Rohingya refugees. The border Guard Bangladesh (BGB) Director General, Major General Anwar Hossain, was quoted saying, 'The patrolling has been intensified and forces have been made alert... so that the violence in the neighbouring country does not affect border security' (June 10, 2012). 
Unambiguous intruder frames were also employed in the The Daily Star, in which Major Shafiqur Rahman, second-in-command of BGB 42 Battalion in Teknaf, said:

As per our informers, Rohingyas on 11 trawlers may attempt to intrude into Bangladesh through Shah Pori Island, Nila, Domdomia and others tonight. We have doubled our forces at these points.

We have already informed our higher authority and we are waiting for instructions on what we will do if such infiltration of Rohingyas occurs. (The Daily Star, June 11, 2012)

In using words such as 'intrude' and 'infiltration' Major Rahman justifies strengthening border security despite the humanitarian crisis. In doing so the newspaper harnesses a number of sub-frames that suggest border sovereignty and integrity is necessity to protect Bangladesh's reputation and protect its citizens from the social contagion of Rohingya deviance and criminality.

The framing in this context defines the problem of striking a balance between strict border control and refugee migration, as one where the interests of the state take precedence over humanitarian obligation, and the moral justification of such a stance is through sub-frames that give precedence to state reputation. In protecting such state interest and reputation, to the exclusion of humanitarian needs the press fail to deliver on its Fourth Estate mandate of scrutiny and accountability.

// intruders of Bangladeshi sovereignty

/// reputational damage to Bangladeshi state identity

/// refugees as a social contagion

/// refugees as threat to law and order and national security

Reputational damage to Bangladeshi state identity: The 'intrusion' as a threat to Bangladeshi identity and reputation is manifest in news reports of the Rohingya obtaining fake identification papers including passports.

On 25 July 2012, The Daily Star reported 'More than 6,000 machine readable passports' had been stolen from the divisional passport office in Agargaon, Dhaka. '...Stolen passports might be used by those who were not legally eligible for a passport, such as Rohingya refugees, convicts and people with a criminal track record'. Reportage on fake passports continued over the next few months, often exaggerating Rohingya involvement. While presenting the Rohingya through a criminality frame, the Bangladeshi government trivialised the involvement of its own citizens. Home Minister Mohiuddin Khan Alamgir said the passport theft in Agargaon was due to 'the negligence of duties of a section of officials' and there was no reason 'to be worried about it' (The Daily Star, October 21, 2012).

Rohingya living in Bangladesh without official papers are indeed likely to pay 
middlemen for fake documents, but it must be argued that the newspaper has the option of framing the Rohingya as outright criminals or as the desperate clientele of Bangladeshi criminals. The majority of Rohingya, even those recognised as legitimate refugees have no legal refugee documentation and are not eligible to obtain Bangladeshi passports. As stateless people sans passports they are unable to obtain travel documents, preventing them from seeking foreign employment abroad while simultaneously unable to secure legitimate employment in Bangladesh or Myanmar, effectively relegating them to continuing cycles of poverty in both countries.

Refugees as a social contagion: 'The newly arrived Rohingyas are now mingling with the local populace, and unless we control this situation, it will become a serious problem for us in the future,' The Daily Star editorial warned on 6 September 2017. This narrative frame is by no means new. 'Rohingyas look similar to Bangladesh people living in the southeast and speak in a dialect which is close to that of Bangladesh people on the border. They can easily mingle with the local people,' a similarly worded Daily Star opinion piece noted on 20 June 2012 (Ur Rashid, June 20, 2012).

In claiming 'unregistered refugees' are 'mingling' with locals, the reports infer such mingling is harmful to the local population, suggesting Bangladesh prefers refugees to be corralled and insulated from the native population. This is a softer framing of what Haynes, Devereux, \& Breen (2004) define as a 'social deviancy' frame.

This social deviancy or social contagion frame adds a harder edge to stories that would traditionally be covered as 'tug-at-the-heart-strings' human-interest articles. In one such example, in a front-page report headlined 'Illegal stay thru' [sic] dubious means', published on 10 July 2012, journalist Julfikar Ali Manik wrote;

A group of policemen last month came across a girl at the entrance to Nayapara Rohingya refugee camp... She wanted to enter the camp 'to meet her sister'. She claimed to be a Bangladeshi, showing her birth certificate. Suspicious, the law enforcers challenged her claims. Faced with questioning, the girl finally admitted to being a Rohingya Muslim living in the area.

The report explores the issue of the Rohingya procuring false documentation including Bangladeshi birth registration for refugee children. The government official who had 'unwittingly' registered the aforementioned Rohingya girl's birth claimed he'd simply made a mistake. Blaming oversight rather than the likelihood of corruption he stated, 'We don't know all those who come to us for birth certificates'. Presented as evidence of the Rohingya damaging Bangladesh's social fabric, the report ignores the difficulties faced by long-term Rohingya refugee children in accessing education and healthcare.

The Rohingya are also disproportionally cited in connection with smuggling 
the common Southeast Asian drug yaba - a methamphetamine and caffeine-based drug that became popular among the Dhaka elite (Thompson, 2017) around 2006. Yaba seizures by the Department of Narcotic Control have increased from about 810,000 tabs in 2010 to 29 million in 2016. Traditionally, the drug was imported across the border from Myanmar, but more recently as the demand for the drug has grown, a number of yaba factories have emerged in Teknaf, operated by 'influential locals' (Chowdhury, 2015). While the Rohingya have certainly been used as drug mules, it is a stretch to assume their migration caused drug smuggling, as the article suggest.

Refugees as a threat to law and order and national security: The front page of the 14 June paper reports on violence spilling into Cox's Bazar from Myanmar, and includes an image of an armed border guard in military fatigues 'reinforcing' security at the Kutupalong Rohingya refugee camps within Cox's Bazar-which clearly frames the Rohingya as aggressors and a threat to public law and order. ...local administration has beefed up security measures, tension prevails
among the people of two Rakhine villages under the upazila and a local-
ity under Teknaf Police Station as they are fearing attack by Rohingya
refugees, who are also aggrieved at the loss of their relatives in Myanmar.
(Barua, June 14, 2012)

Using Rohingya as scapegoats for wider unrest is most stark in the coverage of a series of protests and violent attacks that swept across the Muslim world in response to a YouTube trailer for a film called Innocence of Muslims. On 11 September 2012, members of the Bangladesh Khilafat Andolan group attempted a march on the US Embassy in Dhaka, Bangladesh, marking the start of violent outbursts across the country over the following weeks. On 1 October 2012, in a The Daily Star report on violence in Ramu and Chittagong, Government Home Minister Mohiuddin Khan Alamgir was quoted as saying 'The government is aware of the Rohingya link with the violence'. He said as result, law enforcement had been ordered to maintain vigilance in areas housing Rohingya refugee camps. The minister's claim which conflated the Rohingya with militants, was without evidence, yet went unchallenged in the reportage.

While it is clear the Chittagong violence was a Bangladeshi offshoot of the global Muslim protests, the deliberate placement of blame on the Rohingya, is consistent with the wider narrative of Rohingya criminality and militancy which is at the heart of the newspaper's coverage. However, it must be noted that a small number of news reports such as The Daily Star's front-page article headlined 'tearing out the soul' by Inam Ahmed and Julfikar Ali Manik, from Cox's Bazar, presented the violence in Ramu as a simple Buddhist-Muslim conflict, without any attempt to portion blame on the Rohingya (October 2, 2012). 


\section{Conclusion}

There is little doubt the violence and simmering ethnic tension in Rakhine is a complex socio-historical issue with deep roots. But what is clear from the inductive frame analysis of The Daily Star coverage is that newspaper reportage steeped in nation-state thinking, where belonging is framed through citizenship, and the confines of that state are presented as undisputed, is ill-equipped at fulfilling its Fourth Estate responsibility to scrutinise power. The three framesets identified in this study - the Rohingya as an impediment to Bangladeshi prosperity; Rohingya as victims and the Rohingya as intruders of Bangladeshi sovereignty - and their parent meta-frame of nation-state dominance, demonstrates how the newspaper struggles to break away from socio-political frames set by the hegemony of the nation-state, thus offering little of the insight, scrutiny or pragmatic objectivity expected of a truly independent Fourth Estate. A Fourth Estate bound by such geographic confines clearly fails to represent the interests of the stateless who by definition fall outside of such a limited nation-centric remit.

The frame analysis of The Daily Star suggests the newspaper, at least when it comes to refugee migration, views the twin abstraction of 'state' and 'public' interest as homogeneous. Such a view is deeply problematic in a global world with a global public, moreso within the context of a global Fourth Estate. In popularising the term global village, Marshall McLuhan wrote 'today...we have extended our central nervous system itself in a global embrace, abolishing both space and time as far as our planet is concerned' (1964). Perhaps expecting such a shift in thinking from a state-based Fourth Estate to a global Fourth Estate may be somewhat ambitious, but a call for a broader, regional approach to its fourth-estate mandate is not only called for but essential in fulfilling fundamental obligations of the press in scrutinising power and animating democratic social conscience in and delivering a human-rights based journalism.

The limited remit of a nation-centric state-based media, is being countered to some extent by alternative media such as the Malaysian-based Rohingya satellite television channel Rohingya Vision. In many ways, the satellite television channel launched in April 2012 along with its online media stable has created a Fourth Estate media sphere dedicated to Rohingya interests outside of the traditional nation state structure. With the exception of a few exploratory studies (Downman \& Ubayasiri, 2017; Ma, Pan, Yu, Shi, \& Siu 2018) there is little research on the role of such media, offering much scope for future research in this space. 


\section{References}

Barcus, H. R., \& Halfacree, K. (2018). An introduction to population geographies: Lives across space. New York, NY: Routledge.

Baumgartner, F. R., \& Jones, B. D. (2010). Agendas and instability in American politics. Chicago, IL: University of Chicago Press.

Bhattacharya, B. (1927). Bengali influence in Arakan, Bengal past and present. Journal of the Calcutta Historical Society, 33(65-66), 139-144.

Buchanan, F. (1799). A comparative vocabulary of some of the languages spoken in the Burma empire. Asiatic Researches, 5, 219-240.

Chowdhury, M.A. (2006). The advent of Islam in Arakan and the Rohingyas. [Conference paper]. Retrieved from https:/www.rohingya.org/the-advent-of-islam-in-arakan-andthe-rohingyas/

Chowdhury, S. T. (2015, February 12). Yaba, the 'madness drug', is finding new routes into Bangladesh. Vice News. [Online News] Retrieved from https://news.vice.com/ article/yaba-the-madness-drug-is-finding-new-routes-into-bangladesh.

De Ruyter, K., \& Scholl, N. (1998). Positioning qualitative market research: Reflections from theory and practice. Qualitative Market Research, 7(14). 7-14.

De Vreese, C. H. (2005). News framing: Theory and typology. Information Design Journal \& Document Design, 13(1). 51-62

Downman, S., \& Ubayasiri, K. (2017). Journalism for social change in Asia: reporting human rights. London, UK: Palgrave MacMillan.

Eaton, R. M. (1993). The Rise of Islam and the Bengal Frontier, 1204-1760. Berkeley: University of California Press.

Entman, R. M. (1993). Framing: Towards clarification of a fractured paradigm. Journal of Communication. 43(4), 51-58.

European Commission. (2017). The Rohingya crisis: ECHO factsheet. European Civil Protection and Humanitarian Aid Operations. [Online report]. Retrieved from https:// reliefweb.int/sites/reliefweb.int/files/resources/rohingya_en_2.pdf

Farzana, K. F. (2011). Music and artistic artefacts: Symbols of Rohingya identity and everyday resistance in borderlands. Austrian Journal of South-East Asian Studies, $4(2), 215-236$.

Gamson, W. A., \& Modigliani, A. (1987). The changing culture of affirmative action. In R. G. Braungart \& M. M. Braungart, (Eds.), Research in political sociology, 3, (pp. 137-177). Greenwich, CT: JAI Press.

Gamson,W.A, and Modigliani, A. (1989). Media discourse and public opinion on nuclear power: A constructionist approach. American Journal of Sociology, 95(1), 1-37.

Gitlin, T. (1980). The whole world is watching: The mass media in the making and unmaking of the new left. Berkeley, CA: University of California Press.

Grundy-Warr, C., \& Wong, E. (1997). Sanctuary under a plastic sheet-the unresolved problem of Rohingya refugees. Boundary and Security Bulletin, 79-91. UK: Durhum University International Boundaries Research Unit.

Haksar, N. (2009). Rogue agent: How India's military intelligence betrayed the Burmese resistance. India: Penguin Books India.

Haynes, A., Devereux, E., \& Breen, M. J. (2004). A cosy consensus on deviant discourse: how the refugee and asylum seeker meta-narrative has endorsed an interpretive crisis in relation to the transnational politics of world's displaced persons. [Online article]. Retrieved from https://ulir.ul.ie/bitstream/handle/10344/3632/Haynes_2004_cosy. pdf? sequence $=2$

HRW (Human Rights Watch). (2012, June). 'All you can do is pray': Crimes against 
humanity and ethnic cleansing of Rohingya Muslims in Burma's Arakan state. [Online report]. Retrieved from https://www.hrw.org/report/2013/04/22/all-you-can-do-pray/ crimes-against-humanity-and-ethnic-cleansing-rohingya-muslims

Htin, K. M. (2011). Early Buddhism in Myanmar: Ye Dhammā inscriptions from Arakan. In M. A. Pierre-Yves \& G. W. Mani (Eds.), Early Interactions Between South and Southeast Asia: Reflections on Cross-Cultural Exchange (pp. 385-406) . Singapore: Institute of Southeast Asian Studies.

International Crisis Group. (2016, December 15). Myanmar: A new Muslim insurgency in Rakhine state. [Online report]. Retrieved from https:/www.crisisgroup.org/asia/ south-east-asia/myanmar/283-myanmar-new-muslim-insurgency-rakhine-state

Krishna, S. (1999). Postcolonial insecurities: India, Sri Lanka \& the question of nationhood. Minneapolis, MN: University of Minnesota Press.

Liang, C. (1990). Burma's foreign relations: Neutralism in theory and practice. New York, NY: Praeger Publishers.

Ma, Y., Pan, Z., Yu, F., Shi, Y., \& Siu, Y. Y. (2018). Constructing Rohingya identity: An analysis of media process and self-representations. Global Media Journal, 16(31), $1-10$.

McCombs, M. E., \& Shaw, D. L. (1972). The agenda-setting function of mass media. The Public Opinion Quarterly, 36(2), 176-187.

McCombs, M. (1997). Building consensus: The news media's agenda-setting roles. Political Communication, 14(4), 433-443.

McLuhan, M. (1964). Understanding media. New York, US: McGraw-Hill.

McQuail, D. (2010). McQuail's mass communication theory. London, UK: SAGE.

Morshed, K. (2001). Challenges to democratisation in Burma: Perspectives on multilateral and bilateral responses. International Institute for Democracy and Electoral Assistance. [Online article]. Retrieved from http://archive.idea.int/documents/Burma/ BURMA beyond 2000.pdf

Pearn, B. R. (1944). Arakan and the first Anglo-Burmese war, 1824-25. The Journal of Asian Studies, 4(1), 27-40.

Samers, M., \& Collyer, M. (2017). Migration: Key ideas in geography. New York, US: Routledge.

Scheufele, D. A. (1999). Framing as a theory of media effects. Journal of Communication, 49(1), 103-122.

Schober, J. (2006). Buddhism in Burma: Engagement with modernity. In S. C. Berkwitz (Ed.), Buddhism in world cultures: Comparative perspectives. Oxford: ABC-CLIO.

The Daily Star (2011, December 05). PM goes to Myanmar today. [Online news]. Retrieved from https:/www.thedailystar.net/news-detail-212966

The Daily Star (2011, December 06). Dhaka keen to import gas, electricity. [Online news]. Retrieved from https://www.thedailystar.net/news-detail-213048

The Daily Star (2012, July 10). Illegal stay thru' dubious means. [Online news]. Retrieved from https://www.thedailystar.net/news-detail-241542

The Daily Star (2012, October 02). Tearing out the soul. [Online news]. Retrieved from https://www.thedailystar.net/news-detail-252079

The Daily Star (2012, December 06). Why are Rohingyas being refused entry into Bangladesh? [Online news]. Retrieved from https://www.thedailystar.net/news-detail-238943

The Daily Star (2017, September 21). Rohingya crisis to take a toll on economy: Sanem. [Online news]. Retrieved from https://www.thedailystar.net/business/rohingya-crisistake-toll-economy-sanem-1465144

Thompson, N. A. (2017, August 6). Yaba addiction: The dark side of Bangladesh's 
increasing affluence. CNN [Online news]. Retrieved from http://edition.cnn. com/2017/08/05/asia/methamphetamine-yaba-bangladesh/index.html

UNHCR (2012, October). Office of the High Commissioner for Human Rights' Compilation Report. Universal Periodic Review: Bangladesh. [Online report]. Retrieved from http://www.refworld.org/pdfid/508640242.pdf

UNHCR. (2018, August 15). Rohingya emergency. [Online report]. Retrieved from https://www.unhcr.org/rohingya-emergency.html

Van Gorp, B. (2005). Where is the frame?: Victims and intruders in the Belgian press coverage of the asylum issue. European Journal of Communication, 20(4), 484-507.

Zaller, J. (1992). The nature and origins of mass opinion. Cambridge,UK: Cambridge University Press.

Dr Kasun Ubayasiri is the programme director of the Bachelor of Journalism programme at Griffith University, Queensland, Australia. He is a former Sri Lankan journalist and a journalism researcher specialising in the role of human rights-based journalism in armed conflict. He is a member of the Griffith Centre for Social and Cultural Research (GCSCR), and co-author of Journalism for Social Change in Asia: Reporting Human Rights (2017).

k.ubayasiri@griffith.edu.au
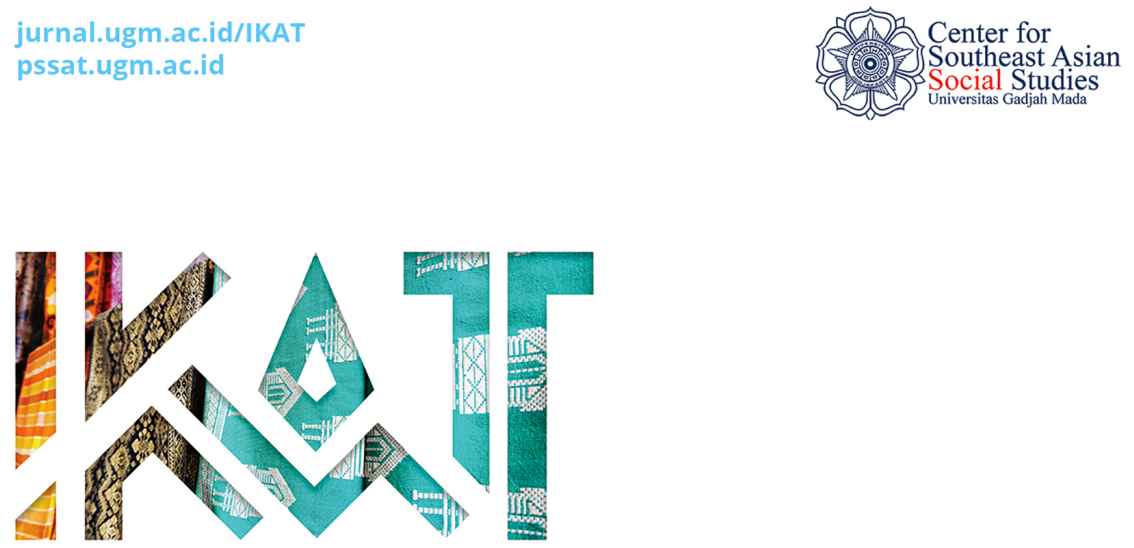

The Indonesian Journal of Southeast Asian Studies

Striving to provide new, rigorous and comprehensive knowledge and understanding of Southeast Asia through inter-disciplinary per-

We look forward to your submission on ugm.id/submissionIKAT 